\title{
Simultaneous determination of clobutinol hydrochloride and doxylamine succinate from syrups by RP HPLC using a new stationary phase containing embedded urea polar groups
}

\author{
Paulo Cesar Pires Rosa ${ }^{1, *}$, Isabel Cristina Sales Fontes Jardim² \\ ${ }^{1}$ Departament of Hard and Earth Science, Institute of Environmental Science, Chemical and Pharmaceutical, Federal \\ University of São Paulo-UNIFESP, Diadema, São Paulo, ${ }^{2}$ Department of Analytical Chemistry, Institute of Chemistry, \\ University of Campinas
}

\begin{abstract}
A new, simple, fast, reproducible and sensitive reversed phase HPLC method, using a new stationary phase containing embedded urea polar groups, has been developed and validated for the simultaneous determination of clobutinol hydrochloride (CLO) and doxylamine succinate (DOX) in syrups. The determination was carried out on a C 8 urea column ( $125 \mathrm{~mm} \times 3.9 \mathrm{~mm}$ i.d., $5 \mu \mathrm{m}$ particle size) synthetized at the Liquid Chomatography Laboratory (LabCrom) of the Chemistry Institute of Unicamp. The mobile phase consisted of a mixture of acetonitrile:methanol:phosphate buffer ( $\mathrm{pH} 2.5)$ in the gradient mode. The diode array detector (DAD) was operated at $230 \mathrm{~nm}$ for CLO and $262 \mathrm{~nm}$ for DOX. The method showed adequate precision, with relative standard deviations (RSD) less than $1 \%$. The presence of the excipients did not interfere in the results of the analysis. Accuracy was determined by adding standards of the drugs to a placebo and good recovery values were obtained. The analytical curves were linear ( $\mathrm{r}^{2} 0.9999$ for CLO and 0.9998 for DOX) over a wide concentration range (2.4-336 $\mu \mathrm{g} \mathrm{mL}^{-1}$ for CLO and 2.3-63 $\mu \mathrm{g} \mathrm{mL}^{-1}$ for DOX). The solutions were stable for at least 72 hours at room temperature. The criteria for validation using the ICH guidelines were fulfilled.
\end{abstract}

Uniterms: Clobutinol hydrochloride/determination. Doxylamine succinate/determination. High performance liquid chromatogralhy/quantitative analysis.

Um novo método simples, fácil e reprodutível, de fase reversa para CLAE, usando uma fase estacionária contendo um grupo polar, uréia, embutido, foi desenvolvido e validado para determinação simultânea de cloridrato de clobutinol (CLO) e succinato de doxilamina (DOX) em xarope. A determinação foi realizada em uma coluna C8 uréia (125 mm x 3,9 mm d.i., $5 \mu \mathrm{m}$ tamanho de partícula) sintetizada em nosso laboratório (LabCrom). A fase móvel consistiu de mistura de acetonitrila:metanol:tampão fosfato pH 2,5, em eluição por gradiente. O detector por arranjos de diodo (DAD) foi utilizado a $230 \mathrm{~nm}$ para CLO e a $262 \mathrm{~nm}$ para DOX. O método apresentou precisão adequada, com desvio padrão relativo menor que $1 \%$. A presença de excipientes não interferiu nos resultados obtidos. A exatidão foi realizada pela adição dos padrões dos fármacos ao placebo e valores de recuperação aceitáveis foram obtidos. As curvas analíticas mostraram-se lineares ( $\mathrm{r}^{2} 0,9999$ para CLO e 0,9998 para DOX) em uma ampla faixa de concentração (2,4-336 $\mu \mathrm{g} \mathrm{mL}^{-1}$ para CLO e 2,3-63 $\mu \mathrm{g} \mathrm{mL} \mathrm{m}^{-1}$ para DOX). A solução padrão foi estável por 72 horas a temperatura ambiente. Os parâmetros de validação foram realizados conforme o guia ICH.

Unitermos: Cloridrato de clobutinol/determinação. Succinato de doxilamina/determinação. Cromatografia líquida de alta eficiência/análise quantitativa.

*Correspondence: P.C.P. Rosa. Departamento de Ciências Exatas e da Terra, Instituto de Ciência Ambiental, Química e Farmacêutica, Universidade Federal de São Paulo - UNIFESP. Rua Prof. Artur Riedel, 275 - Jd. Eldorado, 09972-270 - Diadema - São Paulo, Brazil. E-mail: paulo.pires@unifesp.br 


\section{INTRODUCTION}

Clobutinol hydrochloride, (CLO), 2-(4-chlorobenzyl)-3-(dimethylaminomethyl)butan-2-ol hydrochloride, is widely used as a centrally acting cough suppressant for non-productive cough (Martindale, 1996; USP 31,2008$)$. It is effective and safe, at the recommended daily dose, for coughs from cancer, including advanced cancer cough (Homsi et al., 2001). Clobutinol hydrochloride is not cited in any pharmacopoeia and a literature survey reveals that the number of the analytical methods referring to the drug is relatively limited. The drug has been determined in biological fluids by gas chromatography using surface ionization detection(Ishi et al., 1993). Derivative UV spectrophotometric and high performance liquid chromatographic (HPLC) methods have also been reported (Malliou et al., 2002). Recently, a HPLC method to determine this drug together with some anti-inflammatory drugs in urine has been described (Malliou et al., 2004). A potentiometric ion-selective electrode method based on clobutinol-tetraphenyl borate has also been reported (Issa, Zayed, 2006).

Doxylamine succinate, (DOX), chemically N,Ndimethyl-2-[-methyl-(2pyridyl)benzyloxy] ethylamine hydrogen succinate, is an antihistaminic with antimuscarinic and pronounced sedative effects. It is used for treating nausea during pregnancy and it is present in over the counter cold and sedative pharmaceuticals (Sthal, 1998). Some chromatographic methods have been proposed for its determination at trace levels (Argekar, Sawant, 1999; Argekar, Sawant, 2005), mass spectrometry (Hansen et al., 1985), capillary electrophoresis (Tang et al., 2000), UV spectrometry in a micellar medium (Monferrer-Pons et al., 1996) and Fourier transform infrared spectroscopy (FTIR) (Ventura-Gayete et al., 2006) have also been used. Simultaneous determination of DOX in combination with carbinoxamine maleate by spectrophotometry (MonferrerPons at al., 1996), in combination with dextromethorphan hydrobromide by HPTLC (Indrayanto, 1996), in combination with pseudoephedrine hydrochloride and dextromethorphan hydrobromide by HPLC (Fong, Eickhoff, 1989), and in combination with pyridoxine hydrochloride by HPLC (Argekar, Sawant, 2005) have been reported in the literature. Simultaneous determination of DOX in combination with other antihistamines in pharmaceutical preparations by liquid chromatography with a micelar mobile phase of sodium dodecyl sulfate and pentanol (Paciolla et al., 2001; Gil-Augusti et al., 2001A), of DOX in combination with phenethylamine-antihistamine using $\mathrm{C} 8, \mathrm{C} 18$ or cyano columns with a micellar sodium dodecyl sulfate-pentanol mobile phase (Gil-Augusti et al., 2001B), and of DOX in combination with phenylpropanolamine hydrochloride, chlorpheniramine maleate, dextromethorphan hydrobromide, paracetamol and gaifenesin using ion pair reversed-phase by HPLC, have also been reported.

The simultaneous determination of CLO and DOX by HPLC has not been reported. The objective of this study is to develop a new, simple and fast analytical method using HPLC to quantify CLO and DOX in syrup, followed by a validation study.

\section{EXPERIMENTAL}

\section{Material and reagents}

Clobutinol hydrochloride and doxylamine succinate (Figure 1) were obtained from Forchemic d'Heuman Pharma GMBA (Germany). The standards of CLO and DOX were purchased from United States Pharmacopeia (USP). Potassium dihydrogen phosphate was obtained from J. T. Baker (Eldorado de Mexico, Mexico). Orthophosphoric acid was obtained from Mallinckrodt (Phillipsburg, USA). HPLC grade acetonitrile and methanol were purchased from J.T. Baker (Phillipsburg, USA). Water was deionized and purified by means of a Milipore Milli-Q (Bedford, MA USA). $0.45 \mu \mathrm{m}$ nylon filters were obtained from Millipore. Syrups having clobutinol hydrochloride in combination with doxylamine succinate were purchased on the Brazilian market. A placebo, for the validation study, was prepared with the declared excipients, to verify possible interferences. These were: hydroxyethylcellulose, sodium saccaride, sodium benzoate, sorbitol, water, flavor and glycerol.
A

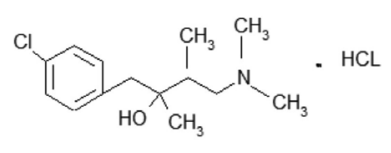

B

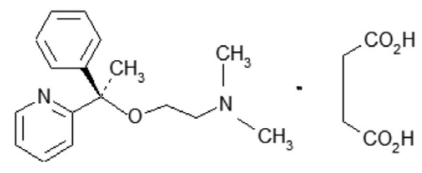

FIGURE 1 - Chemical structures of (A) clobutinol hydrochloride and (B) doxylamine succinate.

\section{Chromatographic instrument and conditions}

The HPLC system used to develop this technique was a Merck-Hitachi Elite LaChrom consisting of a quaternary pump (L-7130), degasser, column oven (L-2300) and automatic injector (L-2200). Quantification and peak purity were checked with a diode array detector (L-2450). Data acquisition was performed using the chromatography software package EZCHrom Elite, version 3.1.3. The pH meter (model 744) was from Metrohm (Herisau-Switzerland). 
The chromatographic separations of CLO and DOX were performed using a $125 \mathrm{~mm}$ x $3.9 \mathrm{~mm}$ i.d. column packed with a C8 urea stationary phase containing an embedded urea (polar) group prepared in our laboratory by a modification of the procedure from preparation of stationary phases with polar groups (Silva et al., 2001, 2002, 2003). The injection volume to carry out the chromatography was set at $5 \mu \mathrm{L}$. The chromatographic parameters: retention factor $(k)$, plate number $(\mathrm{N})$, resolution $\left(\mathrm{R}_{\mathrm{S}}\right)$ and tailing factor (TF) were calculated to evaluate the separation. The detector wavelengths were at $262 \mathrm{~nm}$ for DOX and $230 \mathrm{~nm}$ for CLO.

- Mobile phase

The mobile phase used in this study consisted of a mixture of acetonitrile:methanol:phosphate buffer ( $\mathrm{pH} 2.5)$ in the gradient mode, as shown in Table I. The $\mathrm{pH} 2.5$ phosphate buffer solution was prepared by dissolving $340 \mathrm{mg}$ of potassium monobasic phosphate in $1000 \mathrm{~mL}$ of water; the $\mathrm{pH}$ was adjusted to 2.5 with $10 \% \mathrm{v} / \mathrm{v}$ orthophosphoric acid. The solvents and buffer were filtered through a $0.45 \mu \mathrm{m}$ GH-membrane filter and degassed ultrasonically prior to use. The temperature of the column was held at $25^{\circ} \mathrm{C}$.

TABLE I - Gradient used in separation of CLO and DOX

\begin{tabular}{ccccc}
\hline $\begin{array}{c}\text { Time } \\
(\mathrm{min})\end{array}$ & $\begin{array}{c}\text { Buffer } \\
(\%)\end{array}$ & $\begin{array}{c}\mathrm{MeOH} \\
(\%)\end{array}$ & $\begin{array}{c}\mathrm{ACN} \\
(\%)\end{array}$ & $\begin{array}{c}\text { Flow rate } \\
\left(\mathrm{mL} \mathrm{min}^{-1}\right)\end{array}$ \\
\hline 0 & 77 & 0 & 23 & 1.5 \\
5.0 & 77 & 0 & 23 & 1.5 \\
8.0 & 71 & 2 & 27 & 2.0 \\
12.5 & 71 & 2 & 27 & 2.0 \\
13.5 & 71 & 2 & 27 & 3.0 \\
14.0 & 71 & 2 & 27 & 3.0 \\
15.0 & 77 & 0 & 23 & 2.0 \\
17.0 & 77 & 0 & 23 & 1.5 \\
\hline
\end{tabular}

\section{Preparation of solutions}

- Standard stock solutions

A standard stock solution of DOX was prepared by accurately weighing $45.0 \mathrm{mg}$ of the DOX standard, dissolving it in water and diluting to $100.0 \mathrm{~mL}$ in a volumetric flask $\left(0.45 \mathrm{mg} \mathrm{mL}^{-1}\right)$. A standard stock solution of CLO was prepared by accurately weighing $48.0 \mathrm{mg}$ of the standard of CLO, dissolving it in $5.0 \mathrm{~mL}$ of acetonitrile and diluting it with water in a $100.0 \mathrm{~mL}$ volumetric flask (0.48 $\left.\mathrm{mg} \mathrm{mL}^{-1}\right)$.
- Working solution

A $1.0 \mathrm{~mL}$ volume of the stock solution prepared for DOX and a $5.0 \mathrm{~mL}$ volume of the stock solution of CLO were transferred to $10.0 \mathrm{~mL}$ volumetric flasks. The working solutions were diluted to volume with mobile phase to obtain $45 \mu \mathrm{g} \mathrm{mL}^{-1}$ of DOX and $240.0 \mu \mathrm{g} \mathrm{mL}^{-1}$ of CLO. An aliquot was taken and filtered through a PVDF membrane filter $(0.45 \mu \mathrm{m})$, before injection. For the calibration solutions, aliquots of the standard stock solutions of CLO and DOX were taken in different volumetric flasks and diluted with mobile phase to obtain final concentrations in the range 2.4-336.0 $\mu \mathrm{g} \mathrm{mL}^{-1}$ for CLO and 2.3-63.0 $\mu \mathrm{g} \mathrm{mL}^{-1}$, for DOX.

\section{- Sample solutions}

A $6.0 \mathrm{~mL}$ volume of sample was transferred to a $100.0 \mathrm{~mL}$ volumetric flask, $50.0 \mathrm{~mL}$ of mobile phase was added and the solution was stirred for 10 minutes. After that the solution was diluted to volume with mobile phase. Appropriate proportions were taken and filtered through a PVDF membrane filter $(0.45 \mu \mathrm{m})$ and used for the assays. To verify possible interferences, a placebo was prepared with all of excipients of the syrup and a solution was obtained from dilution of the placebo in mobile phase using the same dilution and procedures used for the preparing sample solution. Each of the solutions prepared were injected in triplicate into the chromatographic system.

\section{Validation of method}

Validation of an analytical method must demonstrate that it fulfills all the requirements of the analytical application, ensuring the reliability of the results. The validation was carried out by studying the parameters specificity, linearity, precision, sensitivity, accuracy, solution stability and limits of detection and quantification adequate for the analysis (ANVISA, 2003; ICH, 1995A; ICH, 1995B; INMETRO 2007).

\section{System suitability}

For system suitability studies, five replicate injections of the mixed standard solution were made, and parameters such as RSD of the peak area, column efficiency, resolution and the tailing factor of the peaks were calculated.

\section{Specificity}

The specificity of the method was investigated by analyzing chromatograms obtained from the placebo, 
mobile phase, standard and sample solutions and comparing the retention times of components of the samples to be analyzed with standards of CLO and DOX. The peak purity of CLO and DOX in the sample and in the standard preparation was also verified by comparisons of the spectra obtained with the diode array detector.

\section{Calibration and linearity}

The linearity of the method was tested in the range of $5-140 \%$ of the target level of the assay concentration of DOX $\left(45 \mu \mathrm{g} \mathrm{mL}^{-1}\right)$ and from 1-140\% of the target level of the assay concentration of CLO $\left(240 \mu \mathrm{g} \mathrm{mL}^{-1}\right)$. Mixed standard solutions containing 2.3-63.0 $\mu \mathrm{g} \mathrm{mL}^{-1}$ of DOX and 2.4-336.0 $\mathrm{g} \mathrm{mL}^{-1}$ of CLO at each linearity point were prepared. The intervals used for linearity was 2.3 , 9.0, 18.0, 27.0, 36.0, 45.0, 54.0 and $63.0 \mu \mathrm{g} \mathrm{mL}^{-1}$ of DOX and 2.4, 24.0, 96.0, 144.0, 192.0, 240.0, 264.0 and 336.0 $\mu \mathrm{g} \mathrm{mL}^{-1}$ of CLO. Each of the levels of concentration was injected in triplicate. In simultaneous determinations, the peak area versus concentration data were performed by linear least-squares regression analysis and the analytical curves were found to be linear for both analytes in the mentioned concentrations.

\section{Detection limit and quantitation limit}

The LOD and LOQ were determined based on signal-to-noise ratios of the analytical responses at 3 and 10 times the background noise, respectively.

\section{Precision}

The precision was evaluated by intraday (repeatability) and interday (intermediate precision) studies. The intraday precision was investigated using six different sample solutions prepared from a syrup at $100 \%$ of the target level for both the analytes. Each solution was injected in triplicate and the peak areas obtained were used to calculate mean and RSD values of each ingredient. The interday precision was checked by preparing, and analyzing in triplicate, six different sample solutions from the syrup at the same concentration levels as used for intraday precision, on different days, by different analysts and/or different HPLC systems (ANVISA, 2003). The percent of the assay for the two components was calculated using the analytical curve.

\section{Accuracy}

The accuracy of the method was evaluated by recovery experiments. The recovery experiments were performed by fortifying the excipient mixture with three known concentrations of the drugs, at the levels of $80 \%$, $100 \%$ and $120 \%$ of the target concentrations $(45 \mu \mathrm{g} \mathrm{mL}-1$ of DOX and $240 \mu \mathrm{g} \mathrm{mL}^{-1}$ of CLO). Three samples were prepared for each recovery level. The amount of DOX and CLO recovered were calculated in relation to the added amount. Each solution was injected in triplicate and peak areas were used to calculate the mean and \% RSD values.

\section{Robustness}

A study of robustness was carried out by testing the susceptibility of the measurements to deliberate variations of the analytical conditions. The factors chosen for this study were the temperature $\left({ }^{\circ} \mathrm{C}\right), \mathrm{pH}$, flow rate $(\mathrm{mL}$ $\min ^{-1}$ ), mobile phase (percentage of acetonitrile), injection volume $(\mu \mathrm{L})$, different columns dimensions.

\section{Solution stability}

To determine the stability of the standard and sample solutions of CLO and DOX, the assay method was carried out after leaving the test solutions of both sample and reference in tightly capped volumetric flasks at room temperature for $72 \mathrm{~h}$. The sample solutions were assayed at $6 \mathrm{~h}$ intervals throughout the study period. Mobile phase stability was also analyzed by assaying the freshly prepared sample solutions against freshly prepared reference standard solutions at $6 \mathrm{~h}$ intervals up to $72 \mathrm{~h}$. Mobile phase was kept constant during the study period.

\section{Stability-indicating ability}

A stability study is an integral part of pharmaceutical product development (ICH, 2006). The data collected during a stability study determine the shelf life, storage conditions and impurity profile of the product. If the assay method itself indicates stability, it is considered to be versatile. Therefore, an attempt was made to investigate the stability-indicating ability of the proposed method. Sample solutions containing $4.0 \mathrm{mg} \mathrm{mL}^{-1}$ of CLO and $0.75 \mathrm{mg} \mathrm{mL}^{-1}$ of DOX, equivalent to the concentrations found in syrups, were kept at $80^{\circ} \mathrm{C}$; or with $1 \mathrm{~mL}$ of $0.1 \mathrm{~mol} \mathrm{~L}^{-1} \mathrm{HCl}$; or $1 \mathrm{~mL}$ of $0.1 \mathrm{~mol} \mathrm{~L}^{-1} \mathrm{NaOH}$; or $1 \mathrm{~mL}$ of $10 \% \mathrm{H}_{2} \mathrm{O}_{2}$ added or in the presence of UV light, each for 24 hours. Simultaneosly, $4.0 \mathrm{mg}$ of CLO and $0.75 \mathrm{mg}$ of DOX in syrup, and a mixture of $4.0 \mathrm{mg}$ of CLO and $0.75 \mathrm{mg}$ of DOX standards were exposed to the same stress conditions. All the exposed standards and syrup samples then were analyzed by the validated method. 


\section{RESULTS AND DISCUSSION}

\section{Optimization of the chromatographic conditions}

The organic solvents acetonitrile and methanol have different effects on the solvation of the analytes and therefore they also affect the symmetry and selectivity of the peaks (Argekar, Sawant, 2005). The best chromatographic condition was obtained with a mobile phase containing a mixture of $27 \%$ acetonitrile, $2 \%$ methanol and $71 \%$ buffer; this condition provided the best resolution of CLO and DOX.

Variations of the buffer concentration helped to achieve a longer retention time for DOX. A decrease in ionic strength leads to an increase in retention for DOX (Pacciolla et al., 2001). A concentration of $0.025 \mathrm{~mol} \mathrm{~L}^{-1}$ $\mathrm{KH}_{2} \mathrm{PO}_{4}$ was the optimum concentration for the separation. A concentration less than $0.020 \mathrm{~mol} \mathrm{~L}^{-1} \mathrm{KH}_{2} \mathrm{PO}_{4}$ increased the retention of DOX and a concentration exceeding $0.030 \mathrm{~mol} \mathrm{~L}^{-1} \mathrm{KH}_{2} \mathrm{PO}_{4}$ resulted in decreased resolution between DOX, CLO and the earlier eluting excipients.

The retention times were also affected by variation of the $\mathrm{pH}$ of the mobile phase. In the $\mathrm{pH}$ range 4.0-5.5 no changes in retention for DOX were observed. At $\mathrm{pH}$ 2.5-4.0 several changes were observed. DOX is capable of being protonated twice, with reported $\mathrm{pKa}$ values of 4.0 (pyridinium group) and 9.2 (tertiary amine group). The rapid increases in retentions as the $\mathrm{pH}$ are due to large concentration of the dication it forms (Sa'sa et al., 1987). A buffer of $\mathrm{pH} 2.5$ was chosen since provides baseline separation with sharp peaks and reasonable retention times.

The good separation between CLO, DOX and the excipients is due to the new stationary phase with embedded polar groups, which shows different selectivities and retentions for basic and polar compounds. This effect can be attributed to the weakening of the interaction between basic analytes and residual silanol groups on the silica surface (Ascah et al., 1996; O'Gara et al., 2001). Some mechanisms that have been proposed are the interaction of the polar function with the unwanted silanols through hydrogen bonding and an increase in the water concentration on the surface because of the hydrogen bonding ability of the polar groups. As a result, the surface layer should have a higher dielectric constant, weakening the interactions between residual surface silanols and basic analytes (Silva et al., 2002). Another advantage is that the phase containing embedded polar groups requires a mobile phase with a lower concentration of organic solvent (Silva et al., 2001).

The wavelengths of $263 \mathrm{~nm}$ and $230 \mathrm{~nm}$ were selected for the UV detection because at these wavelengths there was maximum absorption in the spectra of DOX and CLO, respectively.

\section{Validation of Method}

\section{System suitability}

Results of system suitability parameters are shown in Table II.

TABLE II - System Suitability Parameters

\begin{tabular}{lcc}
\hline Parameters & $\begin{array}{c}\text { Clobutinol } \\
\text { hydrochloride }\end{array}$ & $\begin{array}{c}\text { Doxylamine } \\
\text { succinate }\end{array}$ \\
\hline Plate Number & 13514 & 8964 \\
Retention Time (min) & 13.7 & 7.0 \\
Retention Factor* & 10.4 & 4.8 \\
Resolution & 17.3 & ---- \\
Tailing Factor (5\%) & 1.2 & 1.1 \\
\% RSD peak area & 0.39 & 0.45 \\
\hline
\end{tabular}

$* \mathrm{t}_{\mathrm{M}}$ determined using uracil.

\section{Specificity}

Figure 2 shows chromatograms of standard and sample solutions. The placebo solution afforded three peaks, also observed in the sample solutions, with low retention times with no potential to interfere with the CLO and DOX peaks. In the chromatogram of mobile phase no interference was observed. The retention times of CLO and DOX were similar in the chromatograms of the standard and sample solutions.

The peak purities for CLO and DOX were 0.9993 and 0.9991, respectively, showing that the analyte peaks are pure, without the interference of analog compounds and also that the formulation excipients do not interfer with the analyte peaks.

\section{Calibration and linearity}

The correlation coefficients, linearity range and percent RSD of concentration/area ratio of the analytical curves were calculated and are in Table III.

\section{Detection limit and quantitation limit}

The LOD and LOQ are $0.65 \mu \mathrm{g} \mathrm{mL}^{-1}$ and $2.4 \mu \mathrm{g} \mathrm{mL}^{-1}$ for CLO and $0.62 \mu \mathrm{g} \mathrm{mL}^{-1}$ and $2.3 \mu \mathrm{g} \mathrm{mL}^{-1}$ for DOX, respectively. 

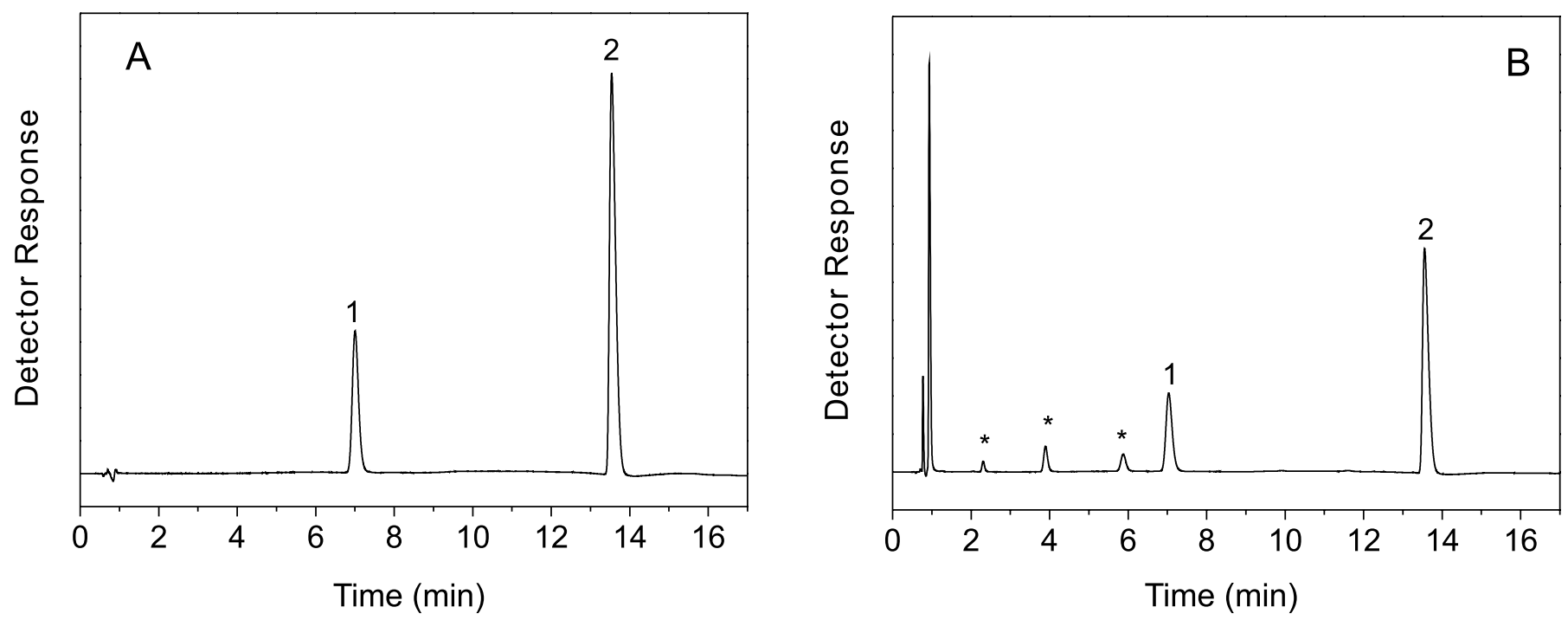

FIGURE 2 - Chromatograms of standard (A) and sample (B) of (1) doxylamine succinate and (2) clobutinol hydrochloride; * excipients. Chromatographic conditions: stationary phase: $5 \mu \mathrm{m}$ Si-C8-urea; column: $125 \mathrm{~mm}$ x $3.9 \mathrm{~mm}$; mobile phase: gradient of MeOH:ACN: $\mathrm{KH}_{2} \mathrm{PO}_{4}$ buffer ( $\mathrm{pH} 2.5$ ); injection volume: $5 \mu \mathrm{L}$; temperature: $25^{\circ} \mathrm{C}$; detection: $262 \mathrm{~nm}$ for DOX and $230 \mathrm{~nm}$ for CLO.

TABLE III - Range of linearity, correlation coefficient and RSD of analytical curves

\begin{tabular}{lccc}
\hline Ingredients & Linearity Range $\left(\mu \mathrm{g} \mathrm{mL} \mathrm{m}^{-1}\right)$ & Correlation coefficient & Concentration/area ratio $(\% \mathrm{RSD})$ \\
\hline Clobutinol & $2.4-336.0$ & 0.99990 & $0.00151-0.8$ \\
Doxylamine succinate & $2.3-63.0$ & 0.99985 & $0.000033-0.6$ \\
\hline
\end{tabular}

\section{Precision}

The assay results and \% RSD, calculated from the peak areas and shown in Table IV, indicate that the method is reliable.

\section{Accuracy}

The recovery values for CLO and DOX ranged from $98.4 \%$ to $100.2 \%$ and $98.8 \%$ to $99.2 \%$, respectively. The average recovery of the three levels (nine determinations) for DOX and CLO were $99.0 \%$ and $99.3 \%$, respectively. The results are shown in Table V.

\section{Robustness}

The results are shown in Table VI. To exemplify the use of the method, a comparation with a X-Terra C8, $150 \times 4.6 \mathrm{~mm}$ i.d., $5 \mu \mathrm{m}$ particle size column from Waters was carried out. The results obtained from analysis with the commercial column were similar to the chromatographic separation from the $\mathrm{C} 8$ stationary phase containing an embedded urea polar group.

\section{Solution stability}

The percent RSD for the assay values determined up

TABLE IV - Precision study and assay results of active ingredients in syrup

\begin{tabular}{lccccc}
\hline Precision & Ingredients & $(\% \mathrm{RSD})$ & $\begin{array}{c}\text { Label value } \\
\left(\mathrm{mg} \mathrm{mL}^{-1}\right)\end{array}$ & $\begin{array}{c}\text { Found } \\
\left(\mathrm{mg} \mathrm{mL}^{-1}\right)^{*}\end{array}$ & \% Label claim \\
\hline Repeatability & CLO & 0.45 & 4.0 & 3.97 & 99.3 \\
& DOX & 0.63 & 0.75 & 0.77 & 102.7 \\
Intermediate precision & CLO & 0.96 & 4.0 & 3.95 & 98.8 \\
& DOX & 0.85 & 0.75 & 0.76 & 101.3 \\
\hline
\end{tabular}

* average of six analyses. 
TABLE V - Accuracy: recovery studies

\begin{tabular}{ccccccc}
\hline $\begin{array}{c}\text { Fortification level } \\
(\%)\end{array}$ & Ingredients & $\begin{array}{c}\text { Amount added } \\
(\mathrm{mg})\end{array}$ & $\begin{array}{c}\text { Amount found } \\
(\mathrm{mg})\end{array}$ & $\begin{array}{c}\text { Recovery } \\
(\%)\end{array}$ & $\begin{array}{c}\text { RSD \% } \\
(\mathrm{n}=3)\end{array}$ & $\begin{array}{c}\text { Average } \\
\text { Recovery }^{*}\end{array}$ \\
\hline 80 & CLO & 3.2 & 3.16 & 98.4 & 0.4 & \\
& DOX & 0.60 & 0.59 & 98.8 & 0.5 & 99.3 \\
100 & CLO & 4.0 & 3.97 & 99.2 & 0.3 & 99.0 \\
& DOX & 0.75 & 0.74 & 99.1 & 0.4 & 0.6 \\
120 & CLO & 4.8 & 4.81 & 100.2 & 0.7 & \\
& DOX & 0.90 & 0.89 & 99.2 & & \\
\hline
\end{tabular}

*Average recovery: the average of the three levels, nine determinations.

to $72 \mathrm{~h}$ for the sample preparation were 0.85 for CLO and 0.76 for DOX; in the standard preparation the values were 0.85 for CLO and 0.76 for DOX. The assay values were within $2 \%$ after 72 hours. The results indicate that the solutions were stable for at least $72 \mathrm{~h}$ at ambient temperature.

TABLE VI - Effect of HPLC experimental parameters on the analysis of CLO and DOX in syrups using Si-C8-urea stationary phase

\begin{tabular}{lccc}
\hline \multirow{2}{*}{ Parameter } & \multirow{2}{*}{ Variation } & \multicolumn{2}{c}{ Recovery $(\%) /$ RSD $(\%)$} \\
\cline { 3 - 4 } & & CLO & DOX \\
\hline Temperature & 27 & $98.1 / 1.3$ & $99.2 / 0.4$ \\
$\left({ }^{\circ} \mathrm{C}\right)$ & 33 & $98.5 / 0.9$ & $99.0 / 0.6$ \\
\hline $\mathrm{pH}$ & 2.3 & $98.7 / 0.7$ & $98.8 / 0.4$ \\
& 2.7 & $98.9 / 0.8$ & $99.1 / 0.3$ \\
\hline Flow rate & $1.5 ; 2.1 ; 3.1$ & $98.8 / 1.1$ & $100.2 / 0.5$ \\
$\left(\mathrm{~mL} \mathrm{~min}{ }^{-1}\right)$ & $1.4 ; 1.9 ; 2.9$ & $98.5 / 1.2$ & $99.5 / 0.7$ \\
\hline Amount of & $>5 \%$ & $99.1 / 0.5$ & $99.7 / 0.8$ \\
acetonitrile $(\%)$ & $<5 \%$ & $98.9 / 0.6$ & $99.3 / 0.4$ \\
\hline Injection volume & 3 & $99.1 / 0.8$ & $100.7 / 0.7$ \\
$(\mu \mathrm{L})$ & 7 & $99.6 / 0.5$ & $100.1 / 0.3$ \\
\hline Column length & $125 \mathrm{~mm} \times 3.9 \mathrm{~mm} ;$ & $100.1 / 0.4$ & $99.5 / 0.7$ \\
& $150 \mathrm{~mm} \times 4.6 \mathrm{~mm}$ & $98.9 / 0.6$ & $99.6 / 0.5$ \\
\hline
\end{tabular}

\section{Stability-indicating ability}

In the chromatograms of samples exposed to heat, alkali, acid and light, no degradation peaks were observed, and the assay values were not changed significantly for either ingredient. However, in the case of samples exposed to a strong oxidizing agent, $\mathrm{H}_{2} \mathrm{O}_{2}$, the assay values of both ingredients were found to decrease significantly. The peaks for CLO/DOX in the chromatograms of all exposed samples were investigated using the DAD detector and were found to be pure. These results are given in Table VII.

\section{CONCLUSION}

The proposed method is simple, precise, accurate and selective for the simultaneous determination of CLO and DOX in syrups. It can be easily and conveniently adopted for routine quality control analysis.

\section{ACKNOWLEDGMENT}

The authors acknowledge financial support from the Brazilian Agencies FAPESP (Fundação de Amparo à Pesquisa do Estado de São Paulo) and CNPq (Conselho

TABLE VII - Assay results of samples exposed to stress conditions

\begin{tabular}{lccccc}
\hline \multirow{2}{*}{ Stress conditions } & \multicolumn{2}{c}{ Amount of drug found $\left(\mathrm{mg} \mathrm{mL} \mathrm{mL}^{-1}\right)$} & \multicolumn{2}{c}{ Peak purity } & \multirow{2}{*}{$\mathrm{R}_{\mathrm{S}}^{*}$} \\
\cline { 2 - 5 } & $\mathrm{CLO}$ & $\mathrm{DOX}$ & $\mathrm{CLO}$ & $\mathrm{DOX}$ & \\
\hline Initial (unexposed sample) & 4.0 & 0.75 & 0.9993 & 0.9991 & 17.3 \\
Acid hydrolysis $\left(0.1 \mathrm{~mol} \mathrm{~L}{ }^{-1} \mathrm{HCl}-24 \mathrm{~h}\right)$ & 3.9 & 0.73 & 0.9985 & 0.9988 & 16.6 \\
Base hydrolysis $\left(0.1 \mathrm{~mol} \mathrm{~L}^{-1} \mathrm{NaOH}-24 \mathrm{~h}\right)$ & 3.8 & 0.72 & 0.9974 & 0.9982 & 17.2 \\
Oxidation $\left(10 \% \mathrm{H}_{2} \mathrm{O}_{2}-24 \mathrm{~h}\right)$ & 2.4 & 0.38 & 0.9915 & 0.9939 & 13.6 \\
Heat $\left(80{ }^{\circ} \mathrm{C}-24 \mathrm{~h}\right)$ & 3.8 & 0.73 & 0.9956 & 0.9965 & 13.6 \\
$\mathrm{UV} \mathrm{Light}\left(25^{\circ} \mathrm{C}-24 \mathrm{~h}\right)$ & 3.9 & 0.71 & 0.9983 & 0.9948 & 16.3 \\
\hline
\end{tabular}

* Resolution between CLO and DOX 
Nacional de Desenvolvimento Científico e Tecnológico). We also thank Prof. C. H. Collins for English revision.

\section{REFERENCES}

AGÊNCIA NACIONAL DE VIGILÂNCIA SANITÁRIA. ANVISA. R E, n ${ }^{\circ} 899$ de 29 de maio de 2003. Guia para validação de métodos analíticos e bioanalíticos. Diário Oficial da União Poder Executivo, Brasilia, 02 jun. 2003. Available at: http://portal.anvisa.gov.br Acessed on: 30 May 2011.

ASCAH, T.L.; KALLURY, K.M.R.; SZAFRANSKI, C.A.; CORMAN, S.D.; LUI, F. Characterization and high performance liquid chromatographic evaluation of a new amide-functionalized reversed phase column. J. Liq. Chromatogr. Rel. Technol., v.19, p.3049-3073, 1996.

ARGEKAR, A.P.; SAWANT, J.G. Simultaneous determination of pyridoxine hydrochloride and doxylamine succinate from tablets by ion pair reversed-phase high-performance liquid chromatography (RP-HPLC). Drug. Dev. Ind. Pharm., v.25, p.945-950, 1999.

ARGEKAR, A.P.; SAWANT, J.G. Simultaneous determination of pyridoxine hydrochloride and doxylamine succinate in tablets by HPTLC. J. Liq. Chromatogr. Relat. Technol., v.22, p.2051-2060, 2005.

FONG, G.W.; EICKHOFF, W.M. Liquid chromatographic determination of amines in complex cough-cold formulations. Int. J. Pharm., v.53, p.91-97, 1989.

GIL-AUGUSTI, M.; MONFERRER-PONS, L.; ESTEVEROMERO, J.; GARCIA-ALVAREZ-COQUE, M.C. Quantitation of antihistamines in pharmaceutical preparations by liquid chromatography with a micellar mobile phase of sodium dodecyl sulfate and pentanol. $J$. AOAC Int., v.84, p.1687-1694, 2001a.

GIL-AUGUSTI, M.; CAPELLA-PEIRÓ, M.E.; MONFERRERPONS, L.; GARCIA-ALVAREZ-COQUE, M.C.; ESTEVEROMERO, J. Chromatograhic analysis of phenethylamineantihistamine combinations using $\mathrm{C}_{8}, \mathrm{C}_{18}$ or cyano columns and micellar sodium dodecyl sulfate-pentanol mixtures. Analyst, v.126, p.457-464, 2001b.

HANSEN Jr., E.B.; THOMPSON Jr., H.C. HPLC determination of the antihistamines, pyrilamine maleate, doxylamine succinate, and triprolidine hydrochloride monohydrate. $L C$ Magazine, v.3, p.986-990, 1985.
HOMSI, J.; WALSH, D.; NELSON, K.A. Important drugs for cough in advanced cancer. Support. Care Cancer, v.9, p.565-574, 2001.

INDRAYANTO, G. Simultaneous densitometric determination of dextromethorphan hydrobromide and doxylamine succinate in syrups and its validation. J. Planar Chromatogr.Mod. TLC, v.9, p.282-285, 1996.

INSTITUTO NACIONAL DE METROLOGIA. INMETRO. Qualidade e Tecnologia. Orientação sobre validação de métodos de ensaios químicos. Rio de Janeiro: INMETRO, 2007. 24 p. (DOQ - CGCRE - 008. Revisão 02).

INTERNATIONAL CONFERENCE ON HARMONIZATION. ICH. Validation of analytical procedures: definitions and terminology. Q2A (CPMP/ICH/381/95). 1995A. Available at: $<$ http://www.ich.org/products/guidelines/quality/article/ quality-guidelines.html>. Accessed on: 30 May 2011.

INTERNATIONAL CONFERENCE ON HARMONIZATION. ICH. Validation of analytical procedures: methodology. Q2B (CPMP/ICH/281/95), 1995B. Available at: <http:// www.ich.org/products/guidelines/quality/article/qualityguidelines.html>. Accessed on: 30 May 2011.

ISSA, Y.M.; ZAYED, S.I.M. Flow injection potentiometric determination of clobutinol hydrochloride. Talanta, v.69, p.481-487, 2006.

JOSEPHS, J.L. Characterization of over-the-counter cough/ cold medications by liquid chromatography/electrospray mass spectrometry. Rapid Commun. Mass Spectrom., v.9, p.1270-1274, 1995.

MALLIOU, E.T.; ANTONIOU, C.G.; KOUNDOURELLIS, J.E. Derivative spectrophotometric and high performance liquid chromatographic determination of clobutinol in pharmaceutical formulations. Anal. Lett., v.35, p.99-109, 2002.

M A L LIOU, E.T.; M A R K A P O U L OU, C.K.; KOUNDOURELLIS, J.E. Simultaneous determination of clobutinol together with some anti-inflammatory drugs in urine by HPLC. J. Liq.Chromatogr. Relat. Technol., v.27, p.1565-1577, 2004.

MARTINDALE. The Extra Pharmacopoeia. 31ed. London: Royal Pharmaceutical Society of Great Britain Press, 1996. p.100-443. 
MONFERRER-PONS, L.; ESTEVE-ROMERO, J.S.; RAMISRAMOS, G.; M.C. GARCIA ALAVAREZ-COQUE, M.C. Spectrophotometric determination of the antihistamines, carbinoxamine maleate and doxylamine succinate, in an $N$-cetylpyridinium chloride micellar medium. Anal. Lett., v.29, p.1399-1413, 1996.

O'GARA, J.E.; WALSH, D.P.; PHOEBE JR., C.H.; ALDEN, B.A.; BOUVIER, E.S.P.; IRANETA, P.C.; CAPARELLA, M.; WALTER, T.H. Embedded-polar-group bonded phases for high performance liquid chromatography. LCGCN.Am. v.19, p.632-642, 2001.

PACIOLLA, M.D.; JANSEN, S.A.; MARTELUCCI, S.A.; OSEI, A.A. A fast and efficient determination of amines and preservatives in cough and cold liquid and suspension formulations using a single isocratic ion-paring high power liquid chromatography method. J. Pharm. Biomed. Anal., v.26, p.143-214, 2001.

SA'SA, S.I.; MOMANI, K.A.; JALAL, I.M. Chromatographic behavior of doxylamine succinate, phenylpropanolamine hydrochloride, chlorpheniramine maleate, dextromethorphan hydrobromide, paracetamol and guaifenesin ion pair reverse-pahse high performance liquid chromatography. Microchem. J., v.36, p.391-398, 1987.

SILVA, C.R.; JARDIM, I.C.S.F.; AIROLDI. C. Development of new urea-functionalized silica stationary phases: characterization and chromatographic performance. $J$. Chromatogr. A., v.913, p.65-73, 2001.
SILVA, C.R.; BACHMANN, S.; SCHEFER, R.R.; ALBERT, K.; JARDIM, I.C.S.F.; AIROLDI. C. Preparation of a new $\mathrm{C} 18$ stationary phase containing embedded urea groups for use in high-performance liquid chromatography. J. Chromatogr. A., v.948, p.85-95, 2002.

SILVA, C.R.; JARDIM, I.C.S.F.; AIROLDI. C., Evaluation of the applicability and the stability of a $\mathrm{C} 18$ stationary phase containing embedded urea groups. J. Chromatogr. A., v.987, p.139-146, 2003.

STAHL, M.S. Psicofarmacologia esencial. Bases neurocientıficas y aplicaciones clınicas. Barcelona: Ed. Ariel Neurociencia, 2002. 688 p.

TANG, Y.F.; WU, H.L.; WU, S.M.; CHEN, S.H.; KOU, H.S. Quantitative chiral analysis of carbinoxamine, doxylamine, and orphenadrine by capillary zone electrophoresis. $J$. Microcol. Sep., v.12, p.366-370, 2000.

VENTURA-GAYETE, J.F.; DE LA GUARDIA, M.; GARRIGUES, S. On-line sample treatment and FT-IR determination of doxylamine succinate in pharmaceuticals, Talanta, v.70, p.1100-1106, 2006.

UNITED STATES PHARMACOPEIA. USP 31. NF 26. Rockville: United States Pharmacopeia Convention, 2008. p.170.

Received for publication on $30^{\text {th }}$ November 2011 Accepted for publication on $09^{\text {th }}$ April 2012 
